\title{
Plagiarism by Academics in Higher Education Institutions: A Case Study of the Journal of Zimbabwe Studies
}

\author{
Evelyn Chiyevo GARWE (Corresponding author) \\ Zimbabwe Council for Higher Education (ZIMCHE) \\ No 21 J.M. Nkomo Road, P. Bag H100 Hatfield Harare, ZIMB.ABWE \\ Tel: 263-772-222-298/263-458-1994 \\ E-mail: garweec@gmail.com/ecgarwe@zimche.ac.zw \\ Elizabeth MAGANGA \\ Zimbabwe Council for Higher Education (ZIMCHE) \\ No 21 J.M. Nkomo Road, P. Bag H100 Hatfield Harare, ZIMB.ABWE
}

Tel: 263-772-222-298/263-458-1994

Email: garweec@gmail.com/ecgarwe@zimche.ac.zw

Received: February 8, 2015 Accepted: February 25, 2015 Published: March 13, 2015

doi:10.5296/ire.v3i1.7060 URL: http://dx.doi.org/10.5296/ire.v3i1.7060

\begin{abstract}
The aim of the study was to explore the incidence and causes of plagiarism amongst academics from higher education institutions in Zimbabwe. A case study approach was used to examine 267 manuscripts submitted to the Journal of Zimbabwe Studies in 2014, by subjecting them to Ithenticate anti-plagiarism software. Interviews were carried out with 105 academics and two editorial staff members to obtain information on reasons for plagiarising. The results showed that $26 \%$ fell within the journal's acceptable similarity index $(0-10 \%)$, $20 \%$ had $11-15 \%$ whilst $54 \%$ had similarity indexes of $16-99 \%$. The major reason for plagiarism was the pressure to satisfy the requirements tenure and promotion. Some academics took advantage of the non-electronic nature of the journal, which reduced the chances of detection. Others argued that the call for manuscripts had not indicated that they
\end{abstract}


would be subjected to plagiarism detection software. Interestingly, when some authors were notified of their plagiarism offences, they indicated that the papers had already been published elsewhere showcasing yet another breach of publication ethics - multiple submission of articles to different journals. These findings raise alarm considering that academics are the torch bearers who ought to exude ethical and academic leadership. Higher education institutions should to take action on this severe violation of ethical, academic and professional standards, fuelled partly by the insistence on publications in a 'publish or perish' profession.

Keywords: plagiarism, academics, scholarly publication; higher education institutions

\section{Introduction}

The requirement for academics in higher education institutions to carry out scholarly research has gathered momentum over the past years. Scholarly research is the pursuit of objective truth through carrying out systematic studies necessary for generating new knowledge in a particular discipline (Bordens \& Abbott, 2007; Graziano \& Raulin, 2009; Hockey, 2000). Research is the kingpin to the advancement of knowledge frontiers for purposes of national development and improving the quality of life for humans, flora, fauna and the environment (Hornby, 1963). In order to produce quality results, research must be premised on specific guidelines and procedures and must fulfil agreed standards (Shugan, 2004). The research process requires the ability to craft a good research proposal; expertise to select an appropriate methodology; data gathering and analytical tools; excellent writing skills targeted at publishing the findings of the study in high impact platforms, appreciation of intellectual property and ability to separate publishable and patentable research output (Bukvova, 2009; Clark \& Hockey, 1989).

Higher education institutions place more prominence on academic research that culminates in conference and poster presentations as well as articles published in refereed journals, books, and book chapters (Bentley \& Blackburn, 1991; Hearn, 1999). Scholarly publications are the outcomes of research work that contributes to the dissemination and archiving of important results through academic, scientific and professional literature and brings credibility and acclaim to researcher(s) and the host institution (Plucker, 1988; Tien \& Blackburn, 1996). Indeed, Whitesides (2004) is of the opinion that research that does not culminate in published papers is not useful at all. Miller (1993) adds “if it wasn’t published, it wasn’t done.”

Issues of integrity in research and scholarly publication are therefore critical in ensuring that research studies lead to significant, original and honest contribution to existing knowledge (Arnold, 2009). Although there are other forms of academic dishonesty and scholarly fraud including fabrication, falsification of data and irresponsible scholarship, plagiarism is considered to be the worst violation of academic and research integrity that threaten honest contribution to knowledge creation (Brateg, 2013; Singh \& Guram, 2014). For the purpose of this paper, plagiarism refers to any of the following acts:

- use (deliberate or unintentional) of other people's concepts, arguments, words or ideas without acknowledging their source; 
- citing the source but using the words verbatim without using quotation marks or a block quotation;

- producing an article whose content or ideas that are too similar to the original work; and

- $\quad$ using information from articles already published by the same author (self-plagiarism).

Quality research and documentation of scholarly publications is time consuming and it takes substantial effort to accomplish. In academia, where teaching staff have to fulfil the inherent professional requirements to 'publish or perish,' some end up cheating (Kock, 1999; Bedeian, 2010). The academic arena often require one to produce a significant number of high impact publications within a short time in order to be recruited, tenured or promoted (Benedict, 1981; Jimoh, 1995; Mwamwenda, 1994; Singh \& Guram, 2014). Resorting to academic plagiarism is premised on the need to search for ways to quickly move up the professional ladder, secure funding, and for ego and personal success (Chop \& Silva, 1991; Maimunah 2013).

Although plagiarism acts are perpetrated at each and every level of scholarship, and are reported to be more widely practised by students (Bennett, 2005; Chireshe, 2014; Roberts, 2008; Trinchera, 2001), this article is dedicated to plagiarism perpetrated by academics. As enshrined in the statutes and regulations for every department, academics in higher education institutions ought to be responsible for teaching, mentoring and making sure that their students avoid plagiarism and any other similar forms of cheating. Academnics are responsible for nurturing new generations of ethical scholars. Indeed, Spender (2004) avers that plagiarism is a pedagogical issue that rests squarely in the hands of lecturers. Previous studies have indicated that academics have also been implicated in acts of plagiarism (Arenson \& Gootman, 2008; Bedeian, Taylor, \& Miller, 2010; Enders \& Hoover, 2006; Harzing, 2010; Honig \& Bedi, 2012; Yentis, 2010). High-profile individual and insititutional cases of plagiarism have been reported in various academic disciplines (Heales \& Westelius, 2002; Standler, 2000; Stoerger, 2002; HPA, 2004).

Researchers have discovered several motives for resorting to plagiarism. For example, Prabhu and Ramasesh (2014) listed the following as incentives for commiting acts of plagiarism:

- inadequate knowledge of the research area;

- poor research skills; poor language competence;

- limited time and poor time management;

- laziness;

- fear of failure;

- $\quad$ pressure to publish for promotion and other rewards;

- $\quad$ vanity and desire for rapid recognition; and

- Absence of enforcement of punitive measures. 


\section{Ml Macrothink}

International Research in Education

ISSN 2327-5499

2015, Vol. 3, No. 1

The assumption made by this study is that all academics are aware of the serious ethical and legal issues associated with plagiarism and logically they would strive to act as role-models. Moreover, they ought to generate and disseminate new knowledge and to uphold high ethical standards since they should be aware of intellectual property issues.

\section{Previous Studies on Plagiarism in Zimbabwe}

A survey of literature on studies carried out in Zimbabwe on plagiarism highlighted four studies. Three of them focused on plagiarism pertaining to undergraduate students (Chireshe, 2014; Gonye, Mareva, Dudu, \& Sibanda, 2012; Kasayira, 2011) whilst one dealt with plagiarism by postgraduate students at Masters level (Chinamasa, 2014). In their study, Chireshe (2014) investigated the views of 30 lecturers and 77 undergraduate students on reasons for perpetrating acts of academic dishonesty and ways of reducing dishonesty. The findings revealed that academic dishonesty inclusive of plagiarism was rife amongst undergraduate students. Interestingly, some students attributed their reason for resorting to academic fraud to be the failure by academics to detect cases of plagiarism. They recommend that lecturers should play their role in academic integrity by being fair, providing deterrents to cheating and eliminating opportunities for cheating. The researcher argued that lecturers might be ignoring cases of student cheating in order to be viewed in good light by students resulting in them giving the lecturer good ratings for teaching. Good ratings for teaching contribute to the lecturers' chances of getting promotion. It is the thesis of this paper that presumably, the major reason why lecturers disregard plagiarism by students is that they themselves, are also guilty of the same offense and hence see nothing wrong with it. This study therefore sought to investigate plagiarism amongst academics in Zimbabwe.

Since academics publish their research in journals, the journals have a responsibility to maintain publication integrity. Nowadays, most journals screen for plagiarism using either open source or commercial digital software such as Turnitin, Euphorus and Ithenticate. These software packages detect similarities with already published papers from databases and websites through the use of algorithms (Culwin \& Lancaster, 2001; Sutherland-Smith, 2010; Walker, 2010). The plagiarism detection software Ithenticate, was used in this study.

The objective of the study was to investigate the extent and causes of plagiarism amongst academics from higher education institutions in Zimbabwe.

\section{Methodology}

A case study approach was used to examine the incidence of plagiarism in manuscripts submitted to the Journal of Zimbabwe Studies in 2014, by subjecting them to Ithenticate anti-plagiarism software. Several researchers have argued that the case study method is the most effective way to study cases of academic plagiarism (Dul \& Hak, 2007; Lewis, 2011; Sonfield, 2014; Stake, 2005). In addition to the case study approach, this study used interviews with academics and editorial staff members to obtain an insight into the mitigating factors for plagiarism amongst academics in higher education institutions. 


\subsection{Procedure for Case Study}

The researcher used documentary analysis to trace the events leading to the publication of the Journal of Zimbabwe studies. Although the Journal commenced in 2011, it only stated using plagiarism detection software in 2014. Accordingly, the documents analysed pertained only to the 2014 edition of the Journal. The process commenced with a call for papers that was distributed to all higher education institutions, inviting academics to submit abstracts for consideration for presentation at the Research and Intellectual Expo and subsequent publication in the Journal of Zimbabwe Studies. The abstracts were sent to peer reviewers for vetting. The authors with selected abstracts were invited to submit full papers. The papers were presented and critiqued at the Research and intellectual Expo 2014 Edition. (The expos are held once a year during the first week of September). The papers were then subjected to a thorough peer review process commencing with a preliminary screening for plagiarism.

The papers were first subjected to Ithenticate anti-plagiarism software. Ithenticate checks whether a manuscript displays content similar to already published articles. The manuscript is first uploaded on the ithenticate website which then generates a report that indicating a similarity index ranging from zero up to 100 percent. The report shows the origin of the matching text or features between uploaded manuscript and the database of existing publications. The matches appear as different colour codes which are linked to the originating source. Since some common names and widely used phrases and other descriptive terms often appear as plagiarised text, the Journal accepts similarity indexes of up to 10 percent. In order to cater for any other eventualities, manuscripts with between 11 and 15 percent similarity index were returned to authors to give then the chance to attend to the plagiarised text. Manuscripts displaying similarity indexes of 16 to 100 percent were rejected out rightly. The authors concerned were notified of the outcome and reminded that plagiarism was an ethical and legal offense.

\subsection{Interviews}

Telephonic interviews were performed with academics from all the 15 registered universities in Zimbabwe. Two sets of interviews were done; the first set included a randomly selected sample representing twenty percent of the academics who had submitted papers to the Journal of Zimbabwe Studies. Theoretically this sample included 54 academics however, some of them where unreachable and some refused to participate in the interview. As a result 30 academics were successfully interviewed. The second set included a purposive sample of five academics for each of the 15 universities. The researcher would make a call to a university general line. The receptionist who answered was asked to transfer the call to any five academic staff members available in any five faculties at the university. This way it was possible for the researcher to speak to a total of 75 academics from all the universities. The names of the contributing academics remained anonymous to the researcher.

The researcher asked all the researchers from the two sets the same question; "In your opinion what are the three major reasons that compel academics to perform acts of plagiarism?" The telephonic interviews lasted for a maximum of three minutes each. The researcher did not make any reference to the Journal of Zimbabwe Studies; they simply asked 
the question that affects all publications in general.

Two key informants from the editorial team of the Journal of Zimbabwe studies were interviewed face to face. They were requested to commend on the extend of plagiarism by contributing authors and to recommend a way forward for the journal, authors, higher education institutions and the nation at large.

\section{Results}

\subsection{The Case Study}

The theme for the call for papers for 2014 was 'Engagement, innovation and diversity for national transformation and development.' A total of 498 abstracts were submitted but 267 were selected for development into full papers. These papers were presented at the Research and Intellectual Expo 2014. The papers were grouped according to the following sub-themes: Education; Religion, Spirituality, Arts and Culture; Humanities and Social Sciences; Management, Leadership and Governance; Agriculture, Environment and Natural Resources; Science, Engineering and Technology and Health and Well-being. Table 1 shows the number of papers in the three categories of similarity indexes under each sub-theme.

Table 1. Ithenticate-derived similarity indexes for articles submitted to the Journal of Zimbabwe studies by sub-theme (2014)

\begin{tabular}{lcccc}
\hline Sub-theme & \multicolumn{2}{c}{ Similarity index } & \multicolumn{2}{c}{ Total } \\
\cline { 2 - 5 } & $0-10 \%$ & $10-15 \%$ & $15-99 \%$ & 69 \\
\hline Education & 14 & 7 & 48 & 30 \\
Religion, Spirituality, Arts \& Culture & 10 & 8 & 12 & 77 \\
Humanities \& Social Sciences & 9 & 6 & 62 & 7 \\
Management, Leadership \& Governance & 5 & 10 & 10 & 27 \\
Agriculture, Environment \& Natural Resources & 7 & 11 & 21 & 41 \\
Science, Engineering \& Technology & 9 & 2 & 4 & 16 \\
Health \& well-being & 10 & 46 & 157 & 267 \\
\hline Total & 64 & & & \\
\hline
\end{tabular}

Table 1 shows that 157 of the 267 manuscripts had similarity indexes ranging from 16 to 99 percent suggesting that the authors had plagiarised. Figure 1 compares the similarity indexes for the seven sub-themes. 


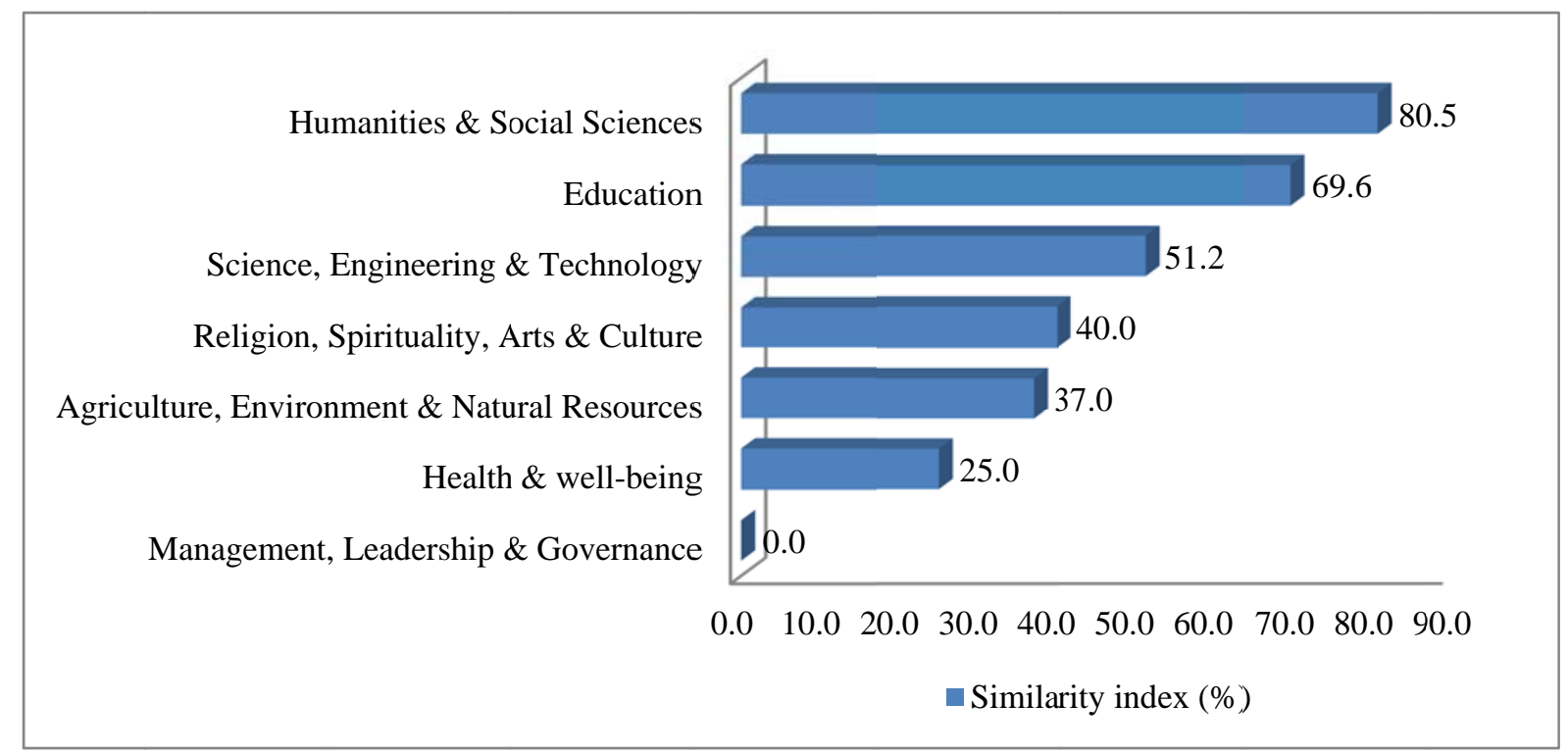

Figure 1. Comparison of the similarity indexes for the seven sub-themes

Figure 1 shows that the only sub-theme without any plagiarism was that of management, leadership and governance. Humanities and social sciences had the highest percentage of plagiarised papers (80.5\%).

Figure 2 shows the percentage of papers falling in the three categories of similarity index.

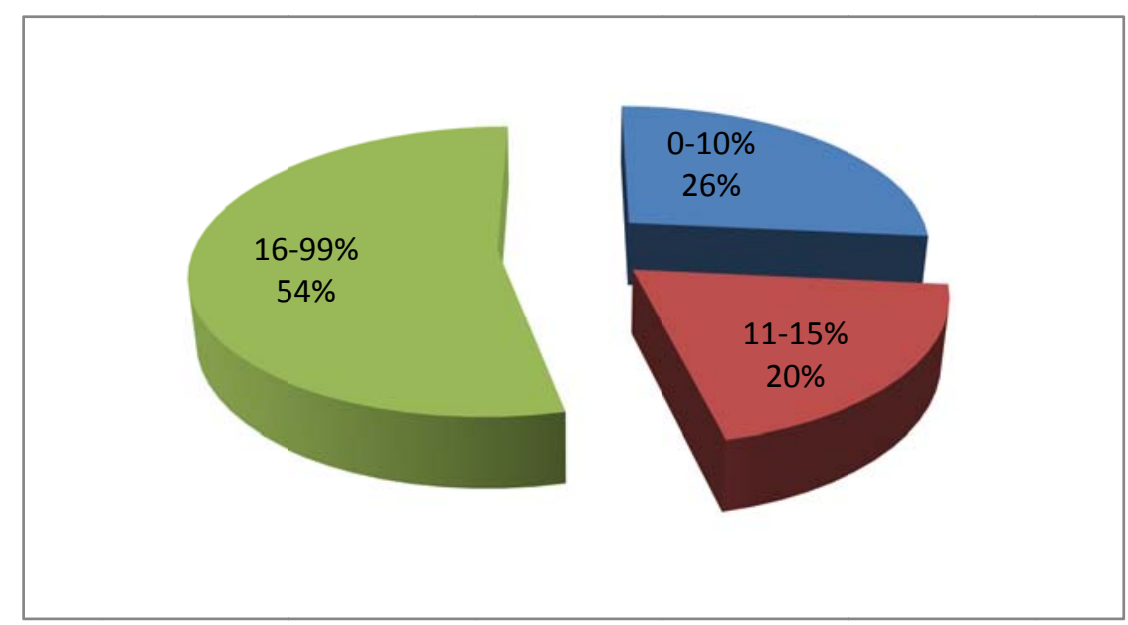

Figure 2: Percentage of papers falling in the three categories of similarity index

Figure 2 shows that only 26\% of the articles complied with the Journal's acceptable similarity index of below10 percent. Twenty percent fell between 11 and 15\% and 54\% had similarity indexes of between 16 and 99\%. 


\subsection{Interviews}

Interviews with academics reflected the reasons shown in Table 2 as the major contributors to plagiarism tendencies among academics in higher education institutions.

Table 2. Reasons for plagiarism amongst academics in higher education institutions

\begin{tabular}{ll}
\hline Reason & Frequency (\%) \\
\hline Pressure to comply with tenure and promotion requirements & 100 \\
Poor writing and research skills; lack of mentorship and vanity & 60 \\
Time constraints due to teaching overload & 50 \\
Hope for no detection and lack of disclosure & 30 \\
Presence of dubious journals & 25 \\
\hline
\end{tabular}

Table 2 shows the five key reasons given by academics for engaging in plagiarism activities. The frequency of mention of the reasons is also shown as a way of providing a ranking for each of the reasons. The assumption being based on the fact that the higher the number of people who mentioned the reason, the greater the judgement of its importance.

The major reason for plagiarism was due to pressure to comply with tenure and promotion requirements. They argued that the circumstances they were operating in were abnormal; they were faced with challenges of funding, resources, laboratories, workshops and equipment to do research. Surprisingly, they were expected to meet the same tenure and promotion standards used internationally. Because they found this requirement very insensitive, they retaliated by using the internet resources wisely or unwisely since it resulted in purported plagiarism. Indeed, the baseline survey performed by the Ministry of Higher and Tertiary Education in 2010, confirmed that the research environment had been compromised by shortage of financial and material resources due to the economic challenges faced by Zimbabwe from 2005 to 2009.

The second reason for plagiarism was the poor research skills attributed to a great number of academics in higher education institutions. Academics admitted that they had limited knowledge in research skills and there was no funding for them to attend short courses, seminars, conferences and workshops were they would network, sharpen their research skills as well as gaining exposure to the scientific world. Academics also blamed their lack of research skills to absence of mentorship by experienced researchers. They mentioned that the majority of academic staff are either junior or senior lecturers with very few occupying the associate and full professor grades. Mentors play an important role in inducting junior lecturers into research (Moses 1985; Mudhovozi, Manganye Mashamba, 2013). These researchers aver that a mentor is a source of guidance on professional advancement. In order to be effective, the mentor should have good writing and time management skills, ability to review literature, apply for funds as well as good ethical judgement. It is interesting to note that the senior academics who were interviewed purported that the budding academics were so proud that it was not easy to mentor them. They exhibited a 'know it all' attitude. Most of the time they would not even ask for advice they just wanted to surprise their seniors with a lot of 
publications to prove their worth. Surprisingly, they never saw the academics carrying out the research.

Academics bemoaned the very high teaching loads as affecting the amount of time they could use for research activities. Lecturers were responsible for teaching conventional, block release and parallel students. This tended to be very time consuming considering that they also needed to mark and set examinations. Lecturers in education, humanities and social studies complained about the huge class sizes they were teaching. At times the clasises were as large as 600 students. In such cases it was almost impossible to research or to engage in further studies.

Academics indicated that they capitalised on the fact that since the journal was not electronic, chances of being detected were low. In addition, the call for papers had not indicated that anti-plagiarism software would be used as part of the preliminary review process.

Interviews with the editorial Secretariat revealed disturbing information to the effect that when some authors were notified that their articles could not be reviewed due to high levels of plagiarism, they indicated that the papers had already been published somewhere. This raised three questions regarding the ethics of authors who submit the same article to different journals as well as the quality of journals that are still accepting articles without using anti-plagiarism software. The third question was directed at higher education institutions who are still promoting staff on the basis of articles published in questionable journals. Beall, (2012) argues that there are publishers who exploit the open access model of publishing by way of charging authors to pay in "suspect" journals of poor quality. The onus is therefore on the higher education institutions to exercise due diligence when considering publications for promotion.

\section{Discussion}

The study clearly showed that plagiarism (54\% of submissions) was a serious problem with academics in higher education institutions in Zimbabwe. This was also confirmed through interviews by the academics, although they proffered various reasons for engaging in unethical conduct of plagiarism even with the full knowledge that such acts are harmful and unacceptable in academia. The results agreed with a study by Honig and Bedi (2012) who investigated 279 articles that were presented at the annual conference organised by the Academy of Management. They discovered moderate and substantial plagiarism from 25\% and $13 \%$ of the papers, respectively. The finding that academics admit practising plagiarism albeit for different reasons is also similar to that of Enders, \& Hoover, (2004) and Bedeian, Taylor, \& Miller, (2010). The study by Enders, \& Hoover, (2004) focused on 1,208 economists. They discovered that $24.4 \%$ of respondents were victims of plagiarism and hence agree that plagiarism amongst academics does exist. Bedeian, Taylor, \& Miller, (2010) reported that 70\% of the academics they interviewed were conscious that their peers had plagiarised. They surveyed 438 academics from 104 business schools.

The reasons for plagiarising flagged by academics in this study are also in tandem with literature. Evidence from other fields suggests that plagiarism is not only wildespread, but often goes undetected. 


\section{MlMacrothink}

International Research in Education

ISSN 2327-5499

2015, Vol. 3, No. 1

The study recommends two strategies to deal with challenges threatening research integrity in Zimbabwean higher education institutions. The first one is capacity building aimed at instilling the importance of research integrity both from an institutional and individual basis. This would include mentoring, awareness and training sessions, workshops, seminars and conferences that focus on research methodologies and the implications and consequences of academic misconduct. The second strategy involves developing and enforcing deterrent and corrective policies and mechanisms to deal with perpetrators of academic misconduct. These policies are already existent with respect to students but not staff members. Higher education institutions should tightly monitor the research activities of their staff. This will allow for detection of publications that are not based on actual research done. The publications should also be thoroughly screened before tenure and promotion is awarded. This will protect the academic integrity of the staff as well as the institutional integrity and reputation.

\section{Conclusion}

The study sought to explore the incidence and reasons of plagiarism amongst academics in higher education institutions using the case of the Journal of Zimbabwe Studies as well as interviews. The results showed alarming levels of plagiarism (54\% of manuscripts). Top among the reasons for plagiarism was the pressure to attain tenure and promotion against a backdrop of poor funding, research facilities and heavy teaching loads. There is need to promote academic integrity in higher education institutions. Two strategies are proposed: capacity building through training sessions, mentorship and workshop attendance as well as developing and enforcing policies for deterring and correcting academics.

\section{References}

Aarrevaara, T., \& Dobson, I. R. (2013). Is there a conflict between teaching and research? The views of engineering academics in Europe. Global Journal of Engineering Education, 15(2).

Arnold, D. N. (2009). Integrity under attack: The State of Scholarly Publishing. SIAM News. Newsjournal of the Society for Industrial and Applied Mathematics, 42(10), 1-4.

Bedeian, A. G., Taylor, S. G., \& Miller, A. N. (2010). Management science on the credibility bubble: Cardinal sins and various misdemeanors. Academy of Management Learning \& Education, 9, 715-725. http://dx.doi.org/10.5465/AMLE.2010.56659889

Bell, J. (2012). Journals that exploit the author-pays model damage scholarly publishing and promote unethical behaviour by scientists. Nature. http://dx.doi.org/10.1038/489179a

Bennett, R. (2005). Factors associated with student plagiarism in a post-1992 university. Assessment \& Evaluation in Higher Education, 30(2), 137-162. http://dx.doi.org/10.1080/0260293042000264244

Bentley, R. J., \& Blackburn, R. T. (1991). Changes in academic research performance over time: A study of institutional accumulated advantage. Research in Higher Education, 31(4), 327-353. http://dx.doi.org/10.1007/BF00992271

Berendt, B. (1981). Improving teaching and learning in higher education. International 
Conference Report, 28 September - 10 October. Berlin (west).

Bretag, T. (2013). Challenges in Addressing Plagiarism in Education. PLoS Med, 10(12), e1001574. http://dx.doi.org/10.1371/journal.pmed.1001574

Bukvova, H. (2009). Research as a Process: A Comparison between Different Research Approaches. Sprouts: Working Papers on Information Systems, 9(29).

Cheema, Z., Mahmood, S., Mahmood, A., \& Shah, M. (2011). Conceptual awareness of research scholars about plagiarism at higher education level: Intellectual property right and patent. International Journal of Academic Research, 3(1), 666-671.

Chireshe, R. (2014). Academic dishonesty: Zimbabwe university lecturers' and students' views. South Africa Journal of Higher Education, 28(1), 45-59.

Chop, R. M., \& Silva, M. C. (1991). Scientific fraud: Definitions, policies, and implications for nursing research. Journal of Professional Nursing, 7, 166-171. http://dx.doi.org/10.1016/8755-7223(91)90051-L

Clark, J. M., \& Hockey, L. (1989). Further research for nursing. New York, NY, USA: Scutari.

Culwin, F., \& Lancaster, T. (2001). Plagiarism, prevention, deterrence \& detection. Institute for Learning and Teaching in Higher Education, South Bank University, U..K.

Divan, A., Bowman, M., \& Seabourne, A. (2013). Reducing unintentional plagiarism amongst international students in the biological sciences: An embedded academic writing development programme. Journal of Further and Higher Education, 1-21. http://dx.doi.org/10.1080/0309877X.2013.858674

Dul, J., \& Hak, T. (2007). Case study methodology in business research. Amsterdam: Butterwork \& Heinemann

Enders, W., \& Hoover, G. (2004). Whose line is it? Plagiarism in Ecomomics. Journal of Economic Literature, 42, 487-493. http://dx.doi.org/10.1257/0022051041409066

Fox, M. F. (1992). Research, teaching and publication productivity: mutuality versus competition in academia. Sociology of Education, 65, 293-305. http://dx.doi.org/10.2307/2112772

Hattie, J. \&Marsh, H. (1996). The relationship between research and teaching: a meta-analysis. Review of Educational Research, 667-542. http://dx.doi.org/10.3102/00346543066004507

Heales, J., Cockcroft, S., \& Westelius, A. (2002). Academic Plagiarism in the IS Community. Report prepared for the AIS Executive Committee, June 2002

Hearn, J. C. (1999). Faculty salary structure in research universities: Implications for productivity. In W. Tierney (Ed.), Faculty productivity: Facts, fictions and issues (pp. 123-173). New York, NY: Falmer Press.

Hooker, S. (1998). Journals - Factors to Consider in Assessing where to Publish? Retrieve 
from whitelab.biology.dal.ca/sh/jrnltext.htm

Honig, B., \& Bedi, A. (2012). The fox in the hen house: A critical examination of plagiarism among members of the academy of management. Academy of Management Learning \& Education, 11(1), 101-123. http://dx.doi.org/10.5465/amle.2010.0084

Hornby, W. (1963). Conducting Educational Research. New York: Harcourt, Brace and Jovenovich.

HPA (2004). Harvard Plagiarism Archives. Retrieve from http://authorskeptics.blogspot.com/

Jimoh, S. A. (1995). Ethical Issues in Research in S. A Jimoh (Ed.) Research methodology in Education. An interdisciplinary Approach, 75-85.

Lewis, B., Duchac, J., \& Douglas Beets, S. (2011). An academic publisher's response to plagiarism. Journal of Business Ethics, 102(3), 489-506. http://dx.doi.org/10.1007/s10551-011-0827-8

Maimunah, I. (2013). Plagiarism: More than Meets the Eye Advances in Language and Literary Studies, 4(2).

Ministry of Higher and Tertiary Education (2010), Baseline study on the status of human capital development and training institutions in Zimbabwe. Machawira, M.S. (ed.)

Moses, I. (1985). Supervising Post-graduates. Kensington, NSW: Canberra: Higher Education Research and Development Society of Australasia.

Mudhovozi, P., Manganye, L., \& Mashamba, T. (2013). Mentors’ Views of Supervising Post-graduate Students undertaking Research at an Institution in Zimbabwe. Journal of Social Science, 37(3), 293-300.

Mwamwenda, T. S. (1994). Academics Stance on the slogan "Publish or Perish". Assessment and Evaluation in Higher Education, 19(2), 99-108. http://dx.doi.org/10.1080/0260293940190203

Plucker, F. E. (1988). Institutional factors that motivate research activity in research universities. Paper presented at the annual meeting of the Association for the Study of Higher Education, St. Louis, MO.

Prabhu Shankar, M. \& Ramasesh, C. P. (2014). Anti-plagiarism Software - A tool to ensure quality research output. In: National Conference on Librarians and Librarianship in Transition: Challenges and Opportunities LIBTRANS 2014, Mangalore.

Purchase, I. F. H. (2004). Fraud, errors and gamesmanship in experimental toxicology. 202 (1-2), 1-20.

Roberts, T. (2008). Student plagiarism in an online world: Problems and solutions. Hershey, PA: Idea Group. http://dx.doi.org/10.4018/978-1-59904-801-7

Shugan, S. M. (2004). Consulting, research and consulting research. Marketing Science, 23(2), 173-179. http://dx.doi.org/10.1287/mksc.1040.0078 
Singh, H. P., \& Guram, N. (2014). Knowledge and Attitude of Dental Professionals of North India Toward Plagiarism North American Journal of Medical Science, 6(1), 6-11. http://dx.doi.org/10.4103/1947-2714.125854

Sonfield, M. C. (2014). Academic plagiarism at faculty level: Legal versus ethical issues and a $\begin{array}{lllll}\text { case study. Journal of Academic } & \text { Ethics, }\end{array}$ http://dx.doi.org/10.1007/s10805-014-9205-3

Stake, R. (2005). The art of case study research. Thousand Oaks: Sage.

Standler R. B. (2000). Plagiarism in Colleges in USA' at http://www.rbs2.com/plag.htm

Stoerger. (2002). Plagiarism. Retrieve from http://www.web-miner.com/plagiarism

Sutherland-Smith, W. (2010). Retribution, deterrence and reform: The dilemmas of plagiarism management in universities. Journal of Higher Education Policy and Management, 32(1), 5-16. http://dx.doi.org/10.1080/13600800903440519

Tien, F. F., \& Blackburn, R. T. (1996). Faculty rank system, research motivation, and faculty research productivity: Measurement refinement and theory testing. Journal of Higher Education, 67(1), 2-22. http://dx.doi.org/10.2307/2943901

Trinchera, T. (2001). Cut and paste plagiarism: What it is and what to do about it. Community and Junior College Libraries, 10, 5-9. http://dx.doi.org/10.1300/J107v10n03_02

Walker, J. (2010). Measuring plagiarism: Researching what students do, not what they say they do. Studies in Higher Education, 35(1), 41-59. http://dx.doi.org/10.1080/03075070902912994

Wells, D. (1993). An account of the complex causes of unintentional plagiarism in college writing. WPA: Writing Program Administration, 16(3), 59-70.

Whitesides, G. (2004). Whitesides Group: Writing a paper. Advanced Materials, 16(15), 1375-1377. http://dx.doi.org/10.1002/adma.200400767

\section{Copyright Disclaimer}

Copyright reserved by the authors.

This article is an open-access article distributed under the terms and conditions of the Creative Commons Attribution license (http://creativecommons.org/licenses/by/3.0/). 